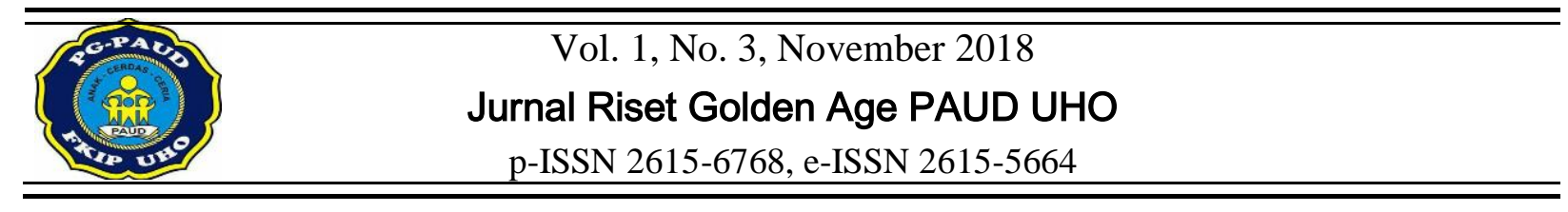

\title{
MENINGKATKAN KEMAMPUAN NATURALIS ANAK MELALUI KEGIATAN PEMBELAJARAN OUTDOOR
}

\author{
Fitri Ayu Fince ${ }^{1)}$, Sitti Rahmaniar Abubakar ${ }^{1)}$ \\ ${ }^{1}$ Jurusan PG-PAUD, Universitas Halu Oleo. Jln. H.E.A Mokodompit, Kendari 93232, Indonesia.
}

\begin{abstract}
Abstrak
Penelitian ini bertujuan untuk meningkatkan kemampuan naturalis anak melalui kegiatan pembelajaran outdoor di kelompok B TK Sangia Jampaka Kecamatan Mawasangka Kabupaten Buton Tengah. Jenis penelitian ini adalah Penelitian Tindakan Kelas (PTK). Penelitian ini dilaksanakan dalam dua siklus. Subjek dalam penelitian ini adalah guru dan anak yang berjumlah 15 orang yang terdiri atas 8 anak perempuan dan 7 anak laki-laki. Berdasarkan hasil belajar anak didik dalam hal kemampuan natuaralis melalui kegiatan pembelajaran outdoor, diperoleh persentase ketuntasan pada siklus I sebesar 66\% dan meningkat pada siklus II sebesar 93\%. Berdasarkan hasil analisis data dari aktivitas mengajar guru pada siklus I sebanyak 10 aspek diperoleh persentase ketercapaian sebesar $60 \%$ sedangkan pada siklus II meningkat menjadi $90 \%$. Pada aktivitas belajar anak didik siklus I diperoleh persentase ketercapaian sebesar 64\% sedangkan aktivitas belajar anak pada siklus II mengalami peningkatan menjadi $91 \%$. Dengan demikian dapat disimpulkan bahwa kemampuan naturalis anak di Kelompok B TK Sangia Jampaka Kecamatan Mawasangka Kabupaten Buton Tengah dapat ditingkatkan melalui kegiatan pembelajaran outdoor.
\end{abstract}

Kata Kunci: Kemampuan Naturalis, Pembelajaran Outdoor, Anak

\section{THE IMPROFING OF CHILDREN NATURALIST ABILITY THROUGH OUTDOOR LEARNING ACTIVITIES}

\begin{abstract}
This research aims to enhance the child's naturalist ability through outdoor learning activities in the group B TK Sangia Jampaka District of Mawasangka Central Buton District. This type of research is class action research (PTK). The study was conducted in two cycles. The subject in this study was a teacher and a child of 15 who consisted of 8 daughters and 7 boys. Based on the learning outcomes of students in the ability of natuaralis through outdoor learning activities, obtained a percentage of the compensation in cycle I of 66\% and increased in cycle II by $93 \%$. Based on the results of data analysis of teacher teaching activity in cycle $I$ as much as 10 aspects obtained percentage of achievement by $60 \%$ while in cycle II increased to $90 \%$. In the learning activities Cycle I gained a percentage of achievement of $64 \%$ while children's learning activities in cycle II experienced an increase to $91 \%$. Thus it can be concluded that the children's naturalist ability in group B TK Sangia Jampaka District of Mawasangka Central Buton District can be improved through outdoor learning activities.
\end{abstract}

Keywords: Naturalist Ability, Outdoor Learning, Children

\section{PENDAHULUAN}

UU No. 20 Tahun 2003 pasal 1 ayat 14, PAUD di Indonesia adalah suatu upaya pembinaan yang ditujukan kepada anak sejak usia 0-6 tahun yang dilakukan melalui pemberian rangsangan pendidikan untuk membantu pertumbuhan dan perkembangan jasmani dan rohani agar anak memiliki kesiapan dalam memasuki pendidikan lebih lanjut.
Anak adalah individu yang unik, kreatif dan aktif karena anak memiliki kemampuan untuk membangun pengetahuannya sendiri. Anak juga merupakan individu yang memiliki berbagai kemampuan yang dapat dikembangkan. Anak belajar melalui kegiatan bermain, mereka memiliki cara belajar yang berbeda dengan orang dewasa.

Wijaya (2008: 1.7) masa kanak-kanak merupakan masa yang fundamental untuk 
mengembangkan berbagai kemampuan yang dimiliki setiap anak, di masa inilah pemberian kesempatan untuk anak dapat mengembangkan kemampuannya melalui kegiatan pembelajaran yang diberikan pendidik untuk menstimulasi pertumbuhan dan perkembangan anak agar dapat berjalan secara optimal.

Ada banyak cara belajar dan anak-anak dapat menggunakan intelegensinya yang berbeda untuk mempelajari sebuah keterampilan atau konsep. Lebih lanjut lagi, bagi Gardner tidak ada anak bodoh, yang ada anak yang menonjol pada satu atau beberapa jenis kecerdasan (Wijaya, 2008: 1.16).

Pada prinsipnya setiap anak mengalami perkembangan dan memiliki kecerdasan ganda yang dapat dikermbangkan. Salah satunya adalah kecerdasan naturalis yang merupakan kecerdasan dalam memahami alam, yang meliputi kemampuan untuk mengidentifikasi dan mengklasifikasikan perbedaan maupun persamaan ciri-ciri diantara spesies baik flora maupun fauna. Disadari bahwa setiap anak memiliki potensi kecerdasan yang tidak sama. Intelligensi yang kedelapan yaitu intelligensi naturalis, yakni kemampuan berkaitan dengan mengenal kembali flora dan fauna serta mencintai alam yang dikembangkan melalui ilmu biologi.

Kemampuan naturalis yaitu mencintai keindahan alam, yang dapat dirangsang melalui pengamatan lingkungan, bercocok tanam, memelihara binatang. Kecerdasan ini memudahkan anak menyukai kegiatan di alam terbuka menumbuhkan kepekaan pada fenomena alam lainnya. Kemampuan naturalis ini dapat dan ditingkatkan serta dipupuk secara efektif melalui strategi pembelajaran yang terarah dan terpadu, yang dikelola dengan memperhatikan aspek perkembangan anak.

Howard Garnerd dalam Sujiono (2005: 6.12) mengemukakan teori tentang multiple intelligences yang menyatakan bahwa kecerdasan naturalis adalah kemampuan untuk mengenali, membedakan, mengungkapkan, dan membuat kategori terhadap apa yang dijumpai dialam maupun lingkungan.

Amrullah (2013: 2) mengemukakan bahwa kemampuan naturalis memiliki ciri antara lain: a) Suka dan akrab pada berbagai hewan peliharaan. b) Sangat menikmati berjalan-jalan dialam terbuka.c) Suka berkebun atau dekat dengan taman dan memelihara binatang. d) Menghabiskan waktu di dekat akuarium atau sistem kehidupan alam. e) Suka membawa pulang serangga, daun, bunga atau benda alam lainnya.

Yulaelawati dalam Rosa (2014: 11) mengatakan bahwa anak yang cerdas naturalis memiliki pola pikir melalui alam dan pola-pola alam, membutuhkan kesempatan berhubungan dengan alam, kesempatan untuk berinteraksi dengan binatang, serta alat untuk menyelidiki alam.

Sefriani (2013: 150-151) anak dengan kemampuan naturalis dapat diamati dari berbagai kemampuan anak yakni: a) Anak memiliki panca indra atau kemampuan sensorik yang baik. Anak mampu melihat dan merasakan dengan lidah dan kulit serta mendengar dengan baik, khususnya spesies dan gejala alam sekitarnya. b) Anak sangat peka terhadap perubahan-perubahan dialam sekitar. c) Anak mampu belajar dan memahami nama-nama hewan dan tanaman beserta karakteristiknya dengan relatif cepat. d) Anak mampu mengenali perbedaan dan persamaan dari berbagai spesies. e) Anak senang berada diluar rumah dan mengamati spesies-spesies disekitarnya. f) Anak tertarik pada gambar-gambar yang bertema alam, tumbuhan dan hewan.

Hal ini juga didukung oleh pendapat Armstrong dalam Tadkiroatun Musfiroh (2008: 8.5) bahwa anak-anak memiliki kemampuan naturalis tinggi cenderung menyukai alam terbuka, akrab dengan hewan peliharaan, dan bahkan menghabiskan waktu mereka didekat akuarium.

Suyadi dalam Rossa (2014: 11) menjabarkan ciri-ciri anak usia 5-6 tahun yang mempunyai kemampuan naturalis tinggi antara lain adalah anak mampu memberi makan hewan peliharaan secara sederhana, mampu menyiram tanaman secukupnya, mampu berkreasi memperindah taman atau halaman.

Berdasarkan pendapat di atas dapat disimpulkan bahwa karakteristis kemampuan naturalis ialah suka berkebun atau dekat dengan tanaman dan memelihara binatang, menyukai bermain dengan binatang, melakukan penyelidikan terhadap alam, menyayangi mahluk hidup lainnya.

Khusus di Kecamatan Mawasangka Kabupaten Buton Tengah, perkembangan naturalis anak masih kurang diterapkan begitu pula di TK Sangia Jampaka Kecamatan Mawasangka Kabupaten Buton Tengah, berdasarkan observasi awal yang telah dilakukan peneliti di TK tersebut khususnya kelompok B, menunjukan bahwa dari jumlah 15 anak hanya 4 
anak didik yang memiliki kemampuan naturalis dengan kriteria Berkembang Sangat Baik (BSB) dan Berkembang Sesuai Harapan (BSH). Hal ini dibuktikan setelah tujuh hari mengamati kegiatan belajar anak. Rendahnya kemampuan naturalis ini terlihat dari anak-anak yang masih kurang menyadari akan pentingnya menjaga lingkungan di sekitarnya dan memelihara tumbuhan dengan baik dan benar, serta kegiatan pengenalan tentang lingkungan dan gejala alam yang dilakukan guru masih kurang untuk meningkatkan kemampuan naturalis anak. Guru di TK tersebut masih menggunakan metode yang berpusat pada guru atau ekspositori yang berarti guru hanya memberikan informasi yang berupa teori generalisasi, sedangkan anak hanya menerima saja informasi yang diberikan oleh guru. Pengajaran telah diolah oleh guru sehingga siap disampaikan kepada anak dan anak belajar dari informasi yang diterimanya itu. Pembelajaran seperti ini hampir tidak ada unsur discovery (penemuan) pada anak usia TK, sehingga pembelajaran akan menjadi sesuatu yang menjenuhkan dan membosankan serta membuat anak tidak memiliki kepekaan terhada lingkungan dan gejala alam karena anak tidak secara langsung dikenalkan kepada alam.

Secara umum pengertian mengajar diluar kelas (outdoor) ialah suatu kegiatan mentransfer knowledge (ilmu pengetahuan) kepada orang lain. Sedangkan pengertian mengajar diluar kelas secara khusus adalah kegiatan belajarmengajar antara guru dan murid, namun tidak dilakukan didalam kelas, tetapi dilakukan di luar kelas atau alam terbuka, sebagai kegiatan pembelajaran siswa. Pembelajaran diluar kelas (outdoor study) merupakan pembelajaran yang dilakukan diluar kelas atau diluar gedung sekolah, atau berada dialam bebas, seperti: Bermain dilingkungan sekitar sekolah, ditaman atau di perkampungan masyarakat sekitar sehingga diperoleh pengetahuan dan nilai-nilai yang berkaitan dengan aktivitas hasil belajar terhadap materi yang disampaikan diluar kelas (Amrullah, 2013).

Vera (2012: 16) metode mengajar diluar kelas bisa kita pahami sebagai suatu kegiatan menyampaikan pelajaran diluar kelas, sehingga kegiatan atau aktivitas belajar mengajar berlangsung diluar kelas atau dialam bebas.

Pendidikan luar kelas merupakan aktivitas luar sekolah yang berisi kegiatan diluar kelas/sekolah dan dialam bebas lainnya, seperti: bermain di lingkungan sekolah, taman, perkampungan pertanian/nelayan, berkemah, dan kegiatan yang bersifat berpetualangan, serta pengembangan aspek pengetahuan yang relevan. Pendekatan pembelajaran diluar kelas menggunakan beberapa metode seperti penugasan, tanya jawab, dan belajar sambil melakukan atau mempraktekan mendorong motivasi belajar anak, karena menggunakan settingan alam terbuka sebagai sarana kelas, untuk memberi dukungan proses pembelajaran secara menyeluruh yang dapat menambah aspek kegembiraan dan kesenangan, dengan situasi belajar sambil bermain.

Pendekatan pembelajaran diluar kelas ini memiliki kelebihan yang mendukung pada pembelajaran siswa, diantaranya sebagai berikut: a. Guru mampu meciptakan suasana pembelajaran yang menyenangkan karena dapat bereksplorasi menciptakan suasana belajar seperti bermain, b. Pada pembelajaran diluar kelas anak menggunakan media pembelajaran yang konkrit dan memahami lingkungan yang ada disekitarnya. Pada saat pembelajaran digunakan media sesuai dengan situasi kenyataannya, yakni berbagai permainan anak seperti seluncuran, ayunan, jungkat jungkit, dan lain-lain, c. Mengasah aktivitas fisik dan kreativitas anak karena menggunakan strategi belajar sambil melakukan atau mempraktekan sesuai dengan penugasan.

Kelebihan dari pembelajaran outdoor menurut Vera (2012: 27) yaitu: a. Mendorong motivasi belajar, doronganmotivasi belajar itu dapat muncul karenakegiatan ini menggunakan setting alam terbuka sebagai sarana belajar, $b$. Suasana belajar yang menyenangkan, dengan metode belajar mengajar diluar kelas, guru bisa lebih mudah menciptakan suasana pembelajaran yang menyenangkan bagi para siswa. c. Mengasah aktivitas fisik dan kreativitas, kegiatan belajar mengajar di luar kelas mampu mengasah aktivitas fisik dan kreativitas para siswa. Hal ini dikarenakan kegiatan ini menggunakan strategi belajar sambil bermain, $d$. Penggunaan media pembelajaran yang konkret, kegiatan belajar mengajar diluar kelas juga memiliki kelebihan disisi penggunaan media pembelajaran yaitu bisa menggunakan media pembelajaran yang konkret dan memahami lingkungan yang ada disekitranya, e. Penguasaan keterampilan sosial, kegiatan belajar mengajar diluar kelas juga mendorong para siswa menguasai keterampilan sosial. Keterampilan ini meliputi keterampilan hidup dan bekerjasama, mengemukakan pendapat serta menghormati orang lain yang berbeda agama, 
suku, budaya, yang mereka temui langsung di luar lingkungan sekolah.

\section{METODE}

Jenis penelitian adalah Penelitian Tindakan Kelas (PTK) atau Classroom Action Research yang dilaksanakan oleh guru didalam kelas. Action Research pada hakikatnya merupakan rangkaian "riset-riset tindakan", yang dilakukan secara siklus, dalam rangka memecahkan masalah, sampai masalah itu terpecahkan. Iskandar (2009: 21) mengatakan bahwa Penelitian Tindakan Kelas (PTK) adalah kegiatan di dalam kelas dalam situasi yang bersifat spesifik dengan tujuan untuk mendiagnosis problem yang juga spesifik, disertai upaya konkret untuk memecahkannya.

Penelitian ini dilaksanakan di kelompok B TK Sangia Jampaka Kecamatan Mawasangka Kabupaten Buton Tengah pada semester genap tahun ajaran 2016/2017 tepatnya pada tanggal 8 Mei sampai 20 Mei 2017.

Faktor-faktor yang diteliti dan diamati dalam penelitian ini adalah sebagai berikut: Faktor guru, aktivitas mengajar guru. Faktor anak, aktivitas belajar dan hasil belajar anak dalam mengikuti kegiatan pembelajaran, dan hasil belajar anak.

Pengumpulan data dalam penelitian ini dihimpun melalui hasil observasi, dokumentasi dan wawancara. Observasi adalah suatu teknik yang dapat dilakukan guru untuk mendapatkan berbagai informasi atau data tentang peremabangan dan permasalahan anak. Observasi dilakukan oleh guru Kelompok B sebagai observer dengan menggunakan lembar observasi. Dokumentasi yaitu mencari data mengenai hal-hal atau variable yang berupa catatan, transkrip, buku, surat kabar, majalah, prasasti, notulen rapat, lengger, agenda dan sebagainya (Arikunto, 2010: 274). Dokumentasi ini berupa foto guru/peneliti pada saat proses meneliti sebagai bukti dalam melakukan kegiatan penelitian di lapangan. Wawancara adalah suatu tehnik pengumpulan data yang dapat dilakukan guru untuk mendapatkan informasi tentang perkembangan dan permasalahan anak dengan cara melakukan percakapan langsung, baik dengan anak maupun orang tua.

Analisis data merupakan cara yang dilakukan untuk mengetahui keefektifan suatu metode dalam kegiatan pembelajaran (Aqib, 2009:203).
Pengelolaan data dalam penelitian ini disesuaikan dengan teknik penilaian di TK yaitu dengan menggunakan tanda sebagai berikut: Belum Berkembang $(\mathrm{BB})=*$, Mulai Berkembang $(\mathrm{MB})=* *$, Berkembang Sesuai Harapan $=* * *$, Berkembang Sangat Baik $=* * * *$ (Depdiknas, 2004: 26).

Tabel 1. Kategori Keberhasilan Klasikal

\begin{tabular}{ccc}
\hline Persentase & Kategori & Simbol \\
\hline $95 \%-100 \%$ & $(\mathrm{BSB})$ & $* * * *$ \\
\hline $85 \%-94 \%$ & $(\mathrm{BSH})$ & $* * *$ \\
\hline $75 \%-84 \%$ & $(\mathrm{MB})$ & $* *$ \\
\hline$<75 \%$ & $(\mathrm{BB})$ & $*$ \\
\hline
\end{tabular}

Dari segi indikator hasil, tindakan dikatakan berhasil apabila anak didik telah mencapai nilai Berkembang Sesuai Harapan (BSH) dan Berkembang Sangat Baik (BSB) minimal $85 \%$ baik secara individual maupun klasikal.

\section{HASIL DAN PEMBAHASAN}

Sebelum kegiatan penelitian ini dilaksanakan, peneliti terlebih dahulu melakukan pertemuan awal dengan kepala Taman Kanak-Kanak Sangia Jampaka Kecamatan Mawasangka Kabupaten Buton Tengah yaitu, pada tanggal 6 Februari 2017, pertemuan ini bermaksud untuk menyampaikan tujuan dari peneliti yaitu mengadakan penelitian di Taman Kanak-kanak Sangia Jampaka Kecamatan Mawasangka Kabupaten Buton Tengah. Selanjutnya, kepala taman kanak-kanak mengarahkan peneliti untuk berdiskusi dengan guru Kelompok B. Setelah itu, peneliti melakukan observasi awal di Taman Kanakkanak Sangia Jampaka Kecamatan Mawasangka Kabupaten Buton Tengah khususnya Kelompok B pada tanggal 9 Februari 2017. Berdasarkan hasil observasi dan dilanjutkan dengan wawancara singkat dengan guru kelompok B di Taman Kanak-kanak tersebut, bahwa dalam kegiatan pembelajaran berbagai pendekatan, metode dan media digunakan dan diterapkan pada proses pembelajaran anak usia dini namun kenyataannya di lapangan masih ditemukan bahwa dalam meningkatkan kemampuan naturalis anak melalui kegiatan pembelajaran outdoor belum dilakukan dengan optimal. Tetapi untuk melakukan kegiatan yang bervariasi bagi anak belum sepenuhnya dilaksanakan, sehingga pada saat observasi awal mengenai meningkatkan kemampuan naturalis 
anak melalui permainan kegiatan pembelajaran outdoor Kelompok B TK Sangia Jampaka Kecamatan Mawasangka Kabupaten Buton Tengah masih berada pada taraf Berkembang Sesuai Harapan (BSH) atau dengan simbol/nilai $(* * *)$.

Berdasarkan permasalahan yang dihadapi tersebut, maka peneliti berusaha merancang suatu kegiatan pembelajaran yang menarik dan menyenangkan bagi anak mengenai meningkatkan kemampuan naturalis anak melalui kegiatan pembelajaran outdoor. Penelitian ini sesuai dengan jadwal yang telah disusun sebelumnya, yaitu dilaksanakan sebanyak dua siklus kegiatan pembelajaran yang masing-masing siklus terdiri dari empat kali pertemuan dengan indikator meningkatkan kemampuan naturalis anak melalui kegiatan pembelajaran outdoor. Peneliti bersama dengan guru Kelompok B melakukan pencatatan nilai pada instrumen penelitian yang sesuai dengan standar penilaian yang diberikan yaitu simbol/nilai bintang yaitu $(*)$ untuk nilai Belum Berkembang (BB), (**) untuk nilai Mulai Berkembang (MB), (***) untuk nilai Berkembang Sesuai Harapan (BSH), dan (****) untuk nilai Berkembang Sangat Baik (BSB).

Penelitian tindakan kelas ini dilaksanakan 2 siklus, masing-masing siklus dilaksanakan dalam 4 tahap yaitu: tahap perencanaan, tahap pelaksanaan tindakan, pengamatan, dan refleksi. Kegiatan penelitian tindakan kelas pada pembelajaran khususnya dalam meningkatkan kemampuan naturalis anak melalui kegiatan pembelajaran outdoor menunjukkan hasil yang baik. Hal ini dapat dilihat dari proses pembelajaran sebagai berikut:.Setiap pertemuan terdiri atas tiga tahap kegiatan yaitu kegiatan awal, kegiatan inti, dan kegiatan akhir. Kegiatan awal, yaitu kegiatan pendahuluan yang dilakukan guru sebelum masuk pada tema pembelajaran yang diawali dengan salam dan membaca doa, memotivasi anak serta memberikan apersepsi yang berhubungan dengan tema pembelajaran.

Pada kegiatan inti di siklus II pertemuan IV dalam meningkatkan kemampuan naturalis anak guru/peneliti bercerita terlebih dahulu tentang tema yang dibawakan yaitu tema air, udara dan api sub tema bahaya api, menanggapi cerita dari guru/peneliti anak merespon dengan berkata" Hari ini kita belajar tentang api lagi ya bu guru"?. Setelah guru/peneliti menjelaskan maksud dari kegiatan yang akan dilakukan, guru/peneliti menggunakan media api untuk menjelaskan kepada anak tentang bahaya api serta kegiatan lainnya yang sudah terencana dalam RPPH.

Guru/peneliti memberi pertanyaan kepada anak terkait dengan bahaya api dan anak menjawab pertanyaan sederhana dari guru/peneliti. "Bahaya api itu bisa membakar tangan bu guru". Selanjutnya masuk pada kegiatan akhir dimana guru mempersiapkan anak untuk merapikan perlengkapan belajar. Kemudian, mempersilahkan anak untuk bermain di luar ruangan atau istrahat kmudian anak dimasukan di dalam ruangan untuk bersiap pulang, sebelum jam pelajaran ditutup, guru/peneliti mengajak anak untuk membuat kesimpulan tentang kegiatan yang telah dilakukan hari ini. Selanjutnya guru/ peneliti mempersiapkan anak untuk pulang dan guru/peneliti membimbing anak untuk mengucapkan syair pulang sekolah, berdoa dan bernyanyi bersama lagu "hati-hati dijalan raya".

Pengamatan terhadap aktivitas mengajar guru meliputi mempersiapkan anak didik untuk belajar, menyampaikan tujuan pembelajaran, melakukan apersepsi dan memotivasi anak, membimbing dan memberikan kesimpulan terhadap kegiatan yang dilakukan.

Hasil analisis pengamatan guru sesuai dengan lembar observasi aspek yang diamati harus dicapai oleh guru/peneliti. Pada siklus II skor yang dicapai guru/peneliti dari 10 aspek hanya 9 aspek tercapai (90\%) diantaranya: (1) menyampaikan tujuan kegiatan ; (2) melakukan apersepsi dengan tema/sub tema (3) guru/peneliti menyediakan media sesuai tema; (4) menjelaskan materi pembelajaran tentang air, udara dan api melalui kegiatan pembelajaran outdoor; (5) mempersilahkan anak menyebutkan manfaat air, udara dan apiyang baru dipelajari sesuai tema/sub tema; (6) mempersilahkan anak menjawab pertanyaan sederhana tentang bahaya api.; (7) mengajukan pertanyaan kepada anak dengan tujuan untuk mengetahui sejauh mana pemahaman anak tentang pembelajaran yang telah diberikan; (8) guru/peneliti mempersilahkana anak melakukan 1-2 perintah sederhana (9) mempersilahkan anak menjelaskan bahaya api sesuai tema. Sedangkan yang tidak tercapai sebanyak 1 aspek $(10 \%)$ : (1) guru/peneliti meminta anak untuk bertanya.

Analisis hasil pengamatan anak didik sesuai dengan lembar observasi pada siklus II sebanyak 11 aspek yang diamati diharapkan tercapai, namun yang tercapai sebanyak 10 aspek (91\%) diantaranya : (1) anak 
mendengarkan guru/peneliti menyampaikan materi pembelajaran; (2) anak menyebutkan media tumbuhan yang diperlihatkan; (3) memperlihatkan sikap bersahabat baik dengan guru/peneliti maupun dengan temannya; (4) kemampuan memahami pembelajaran yang dijelaskan oleh guru/peneliti; (5) anak dapat menjelaskan bahaya apiyang baru dipelajari sesuai tema; (6) anak dapat menyelesaikan tugas yang diberikan oleh guru/peneliti (7) anak dapat menjawab pertanyaan sederhana mengenai bahaya api; (8) anak dapat mengajukan pertanyaan (9) anak dapat menyebutkan bahaya api yang baru dipelajari sesuai tema/sub tema; (10) anak dapat melakukan 1 samapi 2 perintah sederhana. Sedangkan yang tidak tercapai sebanyak 1 aspek (9\%) diantaranya: (1) aktif dan senang memperagakan gerakan yang berhubungan dengan tema/sub tema.

\section{PENUTUP}

\section{Kesimpulan}

Dari hasil penelitian dan observasi yang telah dilakukan pada anak didik kelompok B Taman Kanak-kanak Sangia Jampaka Desa Tanai landu Kecamatan Mawasangka kabupaten Buton Tengah dapat disimpulkan telah tercapai peningkatan kemampuan naturalis anak melalui kegiatan pembelajaran outdoor sesuai indicator kinerja yang ditetapkan.

\section{Saran}

Berdasarkan kesimpulan tersebut dapat dikemukakan saran dalam meningkatkan kemampuan naturalis anak melalui kegiatan pembelajaran outdoor sebagai berikut: (1) bagi guru dalam meningkatkan kemampuan naturalis anak, guru sebaiknya menerapkan kegiatan pembelajaran outdoor, (2) bagi sekolah memberikan dan menyediakan fasilitas dalam meningkatkan kemampuan naturalis anak melalui kegiatan pembelajaran outdoor, (3) bagi peneliti selanjutnya mengenai meningkatkan kemampuan naturalis anak melalui kegiatan pembelajaran outdoor masih banyak kekurangan dan jauh dari sempurna. Oleh karena itu, menjadi motivasi bagi peneliti selanjutnya untuk melengkapi penelitian ini, yaitu dengan variasi yang lebih beragam, sehingga lebih meningkatkan kemampuan naturalis anak melalui kegiatan pembelajaran outdoor sebagai pembelajaran pada anak usia dini.

\section{DAFTAR PUSTAKA}

Amrullah, dkk. 2013. Kecerdasan Naturalis Perkembangan Psikologi. Jakarta: Universitas Islam Negeri. Tersedia: (http://rohimzoom. blogsot.com/, diakses Januari 2016).

Aqib, Zaenal, dkk. 2011. Penelitian Tindakan Kelas untuk Guru SD, SLB, dan TK. Bandung: Yrama Widya.

Arikunto, Suharsimi. 2010. Prosedur Penelitian Suatu Pendekatan Praktek. Jakarta: Rineka Cipta.

Depdiknas. 2004. Pedoman Penilaian di Taman Kanak-Kanak. Jakarta: Depdiknas.

Iskandar. 2009. Penelitian Tindakan Kelas. Jakarta: Gaung Persada (GP) Press.

Iskandar. 2009. Penelitian Tindakan Kelas. Jakarta: Gaung Persada (GP) Press.

Musfiroh, Tadkiraotum. 2008. Pengembangan Kecerdasan Majemuk. Jakarta: Universitas Terbuka.

Rossa, Vika Oktia. 2014. Mengoptimalkan Kecerdasan Naturalis Anak Usia Dini Melalui Pembelajaran Sains Dengan Media Boneka Horta. Bengkulu.

Sefriani, Andin. 2013. Deteksi Minat Bakat Anak, Optimalkan 10 Kecerdasan Anak. Jakarta: Media Pressindo.

Sujiono, Yuliani, dkk. 2005. Perkembangan Kognitif (edisi 1). Jakarta: Universitas Terbuka.

Vera, Adelia. 2012. MetodeMengajarAnak Di LuarKelas (Outdoor Study). Yogyakarta: Diva Press.

Wijaya, Widarmi D, dkk. 2008. Kurikulum Pendidikan Anak Usia Dini. Jakarta: Universitas Terbuka. 